\title{
PENGARUH PEMBATASAN INTERAKSI SOSIAL DI MASA PANDEMI COVID-19 PADA ANAK USIA DINI
}

\author{
Syahrida Norkhalifah \\ Mahasiswa S1 Psikologi Universitas Lambung Mangkurat \\ e-mail: syahridanorkhalifah060703@gmail.com
}

\begin{abstract}
Abstrak
Tujuan dari penulisan artikel ini adalah untuk memenuhi tugas yang diberikan pada mata kuliah filsafat umum sekaligus untuk memaparkan informasi tentang pengaruh pembatasan interaksi sosial di masa pandemi covid 19 pada anak usia dini. Metode yang digunakan adalah metode kajian literatur. Data yang dikumpulkan diambil dari beberapa sumber seperti jurnal. Kesimpulan yang didapat dari pengumpulan data pada artikel ini adalah pembatasan interaksi sosial sangatlah memiliki dampak bagi anak usia dini, karena anak membutuhkan interaksi sosial untuk bisa membangun karakternya dan interaksi sosial merupakan salah satu hal yang memiliki peran penting dalam proses perkembangan sosial maupun moral pada anak.
\end{abstract}

\section{Kata Kunci: Interaksi Sosial, Covid 19, Anak Usia Dini}

\section{A. Pendahuluan}

Pada tahun 2020 ini, dunia diserang oleh virus yang dinamai dengan virus Covid-19. Virus ini adalah salah satu jenis virus yang sedang menyebar di seluruh dunia pada tahun 2020. Penyebaran virus yang menyebabkan penyakit Covid-19 ini membuat masyarakat melakukan pembatasan sosial sebagai antisipasi penularan. ${ }^{[1]}$ Dan juga, pemerintah menghimbau masyarakat untuk membatasi berinteraksi dengan orang lain dan meminimalisir masyarakat untuk keluar dari rumah masing-masing atau biasa disebut dengan social distancing.

Kata interaksi secara umum dapat diartikan sebagai kegiatan saling berhubungan atau pun saling bereaksi yang terjadi pada dua orang individu atau lebih. Sedangkan sosial adalah berkenaan dengan masyarakat(Wiyono, 2007:234). Pada dasarnya, manusia itu adalah makhluk sosial, yaitu makhluk yang memerlukan orang lain untuk keberlangsungan hidup yang dijalaninya. Manusia berusaha menjalin hubungan yang baik dengan orang lain, baik itu dengan orang yang lebih tua atau dengan yang lebih muda darinya, bahkan dengan teman seusianya atau teman sebaya. ${ }^{[2]}$ Akan tetapi, karena adanya pandemi Covid19 di tahun 2020 ini memaksa manusia untuk melakukan pembatasan interaksi secara langsung satu sama lainnya. Interaksi sosial sangatlah dibutuhkan dalam kehidupan sosial, karena interaksi sosial merupakan kunci dari kehidupan sosial itu sendiri. Terutama untuk seorang anak, interaksi sosial merupakan salah satu hal yang dibutuhkan oleh anak untuk bisa membangun karakter dan kemampuan sosialnya dalam berinteraksi dengan orang lain. Proses perkembangan pada anak usia dini terjadi secara pesat dan fundamental bagi kehidupan selanjutnya. Anak usia dini sendiri adalah anak yang berusia antara 0-8 tahun. Pada fase ini, proses pertumbuhan dan perkembangan dalam berbagai aspek terjadi, dan diantaranya yaitu aspek moral dan interaksi sosial. ${ }^{[3]}$

B. Metode

.Metode adalah salah satu bagian penting dalam suatu penulisan artikel. Pada penulisan artikel ini, metode yang saya gunakan adalah metode kajian literatur. Cooper 
dalam Creswell mengemukakan bahwa kajian literatur memiliki beberapa tujuan yaitu memberitahukan kepada pembaca akan hasil penelitian lain yang berhubungan erat dengan penelitian yang dikerjakan saat itu, mengaitkan penelitian dengan literatur-literatur yang ada, dan mengisi celah-celah dalam penelitian-penelitian sebelumnya. ${ }^{[4]}$

Kajian literatur merupakan media yang penting, karena literatur sangat berguna dan menolong dalam hal memberi konteks juga arti di dalam penulisan yang sedang dikerjakan, lalu melewati kajian literatur ini juga peneliti bisa menyampaikan dan membuat pembaca mengetahui, kenapa hal yang ingin diteliti merupakan masalah yang memang harus diteliti, baik dari segi subjek yang akan diteliti maupun lingkungan mana pun dari sisi hubungan penelitian dengan tersebut dengan penelitian lain yang relevan(Afifuddin, 2012). ${ }^{[5]}$ Artikel ini terbentuk dari beberapa jurnal yang saya kumpulkan sesuai dengan topik yang saya bahas pada artikel ini, yang kemudian saya kumpulkan sehingga dapat membentuk artikel ini.

\section{Hasil dan Pembahasan}

Pada usia 0 sampai 8 tahun, seorang anak membutuhkan interaksi sosial dari sekitarnya selain keluarga dan mulai mengembangkan perilakunya sesuai dengan lingkungan sosialnya. Dengan adanya interaksi sosial, anak mendapat banyak informasi di sekitarnya dan memahami akan pentingnya suatu kepedulian kepada orang lain. Pembentukan perilaku anak dengan mengembangkan moral dapat dilakukan melalui pembiasaan yang terwujud dalam keadaan sehari-hari, hal ini bertujuan untuk mempersiapkan anak sedini mungkin dalam mengembangkan sikap dan perilaku yang dilandasi moral pancasila. ${ }^{[6]}$ Anak membutuhkan orang lain selain orang tua untuk membantu dalam perkembangan penalaran moralnya. Anak usia dini pada umumnya akan menolong orang lain jika mereka berpendapat bahwa yang mereka lakukan benar secara moral, hal ini karena penilaian moral pada anak usia dini ditimbulkannya melalui emosi (Turiel \& Killen, 2010). ${ }^{[7]}$ Walaupun perkembangan penalaran moral berlangsung secara berkelanjutan sesuai dengan urutan dan juga tahapannya, anak tetaplah membutuhkan orang tua, guru, dan juga teman sebaya untuk membantu mereka bergerak menuju kematangan tingkatan dalam penalaran(Boyes dan Allen; Hann, Langer dan Kohlberg; Hoffman dan Saltzstain; Parik dan Powers, dalam Ijzendoorn, 1997). ${ }^{[8]}$ Akan tetapi pembatasan interaksi sosial yang terjadi sekarang ini membuat anak lebih sering berdiam diri di rumah dan membuat interaksi anak terbatas hanya kepada orang terdekatnya saja.

Pada usia 4-5 tahun, anak-anak tidak hanya menggambarkan diri mereka dalam sifatsifat psikologis, tetapi mereka melihat orang lain. ${ }^{[9]}$ Dengan melihat dan memperhatikan orang lain, anak menambah wawasan dan pengetahuannya dalam ruang lingkup sosial. Kebanyakan dari informasi tersebut diperoleh oleh anak-anak dari kegiatan bermainnya. Bermain adalah suatu kegiatan yang menyenangkan untuk anak-anak, karena pada dasarnya dunia anak-anak adalah dunia bermain. Ketika bermain anak-anak bebas mengekspresikan perasaannya, seperti rasa marah, sedih, senang, gembira, dan puas. ${ }^{[10]}$ Apalagi bila anak bermain bersama temannya secara berkelompok, anak bisa mendapatkan lebih banyak informasi dari segala macam emosi yang diperlihatkan oleh teman-temannya daripada bermain sendirian. Karena hal itu, interaksi sosial pada anak usia dini memanglah sangat dibutuhkan karena anak nantinya akan diajarkan bagaimana hidup bermasyarakat, 
lalu anak juga akan diajarkan berbagai peran yang nantinya akan menjadi indentifikasi dirinya, selain itu pula saat melakukan interasi sosial anak akan memperoleh berbagai informasi yang ada disekitarnya. ${ }^{[11]}$ Akan tetapi, pembatasan interaksi sosial pada masa pandemi ini membuat ruang lingkup sosial seorang anak terbatas, mereka tidak bisa keluar rumah dan bermain bersama teman sebaya dengan leluasa. Pembatasan interaksi sosial pada anak bisa mempengaruhi perkembangan sosial pada anak. Perkembangan sosial adalah suatu pencapaian kematangan dalam hubungan sosial, bisa juga diartikan sebagai proses belajar untuk menyelaraskan diri dengan norma, moral, dan juga tradisi, yaitu membaurkan diri menjadi suatu kesatuan yang saling berkomunikasi dan bekerjasama. ${ }^{[12]}$ Hal ini dapat berdampak pada keadaan psikologis seorang anak dan bisa membuatnya asing dengan lingkungan sosialnya nanti dan membuatnya enggan untuk berinteraksi dengan orang lain.

\section{Kesimpulan}

Dari hasil dan juga pembahasan di atas, dapat ditarik kesimpulan bahwa pembatasan interaksi sosial memiliki pengaruh yang besar bagi anak usia dini dalam segi perkembangan karakter dan perilaku anak dalam bersosial, karena dengan adanya pembatasan tersebut ruang lingkup seorang anak dalam bersosial menjadi sempit yang menyebabkan kurangnya interaksi anak dengan orang lain. Hal ini dapat berdampak pada perilaku anak ketika turun di lingkungan sosial nanti, karena itu menganggap remeh adanya pembatasan interaksi sosial ini bukanlah hal yang patut dimiliki karena mungkin saja menyebabkan timbulnya dampak negatif pada perkembangan sosial pada anak.

\section{Daftar pustaka}

[1] Masrul, M., Tasnim, J. S., Daud Oris Krianto Sulaiman, C. P., Purnomo, A., Febrianty, D. H. S., Purba, D. W., \& Ramadhani, Y. R. (2020). Pandemik COVID-19: Persoalan dan Refleksi di Indonesia. Medan: Yayasan Kita Menulis.

[2] Ansyah, R., Safitri, J., \& Zwagery, R. V. (2020). HUBUNGAN PERSEPSI COPARENTING DENGAN INTERAKSI TEMAN SEBAYA PADA SISWA SEKOLAH MENENGAH PERTAMA NEGERI 2 MARTAPURA. Kognisia prodi Psikologi FK ULM, 2(1), 15-25.

[3] Novitasari, W., \& Khotimah, N. (2016). Dampak penggunaan gadget terhadap interksi sosial anak usia 5-6 tahun. PAUD Teratai, 5(3).

[4] Pebriana, P. H. (2017). Analisis penggunaan gadget terhadap kemampuan interaksi sosial pada anak usia dini. Jurnal Obsesi: Jurnal Pendidikan Anak Usia Dini, 1(1), 1-11.

[5] Yusuf, S. A., \& Khasanah, U. (2018). Kajian Literatur Dan Teori Sosial Dalam Penelitian.

[6] Fitriyana, R., Zwagery, R. V., \& Safitri, J. (2020). PERBEDAAN PERILAKU MENOLONG PADA ANAK USIA DINI YANG DIBERIKAN CERITA MORAL YANG MENEKANKAN EMOSI NEGATIF PENGAMAT DENGAN CERITA NONMORAL DI PAUD IDAMAN BANJARBARU. Jurnal Kognisia: Jurnal Mahasiswa Psikologi Online, 2(2), 95-101.

[7] Fauziah, A., Zwagery, R. V., \& Mayangsari, M. D. (2020). PERBEDAAN PERILAKU MENOLONG ANAK USIA DINI YANG DIBERIKAN CERITA MORAL YANG 
MENEKANKAN EMOSI POSITIF PENGAMAT DAN CERITA NONMORAL. Jurnal Kognisia: Jurnal Mahasiswa Psikologi Online, 2(2), 55-63.

[8] Yuniarrahmah, E., \& Rachmah, D. N. (2016). Pola asuh dan penalaran moral pada remaja yang sekolah di madrasah dan sekolah umum di Banjarmasin. Jurnal Ecopsy, 1(2).[b]

[9] Sukatin, Q. Y. H., Alivia, A. A., \& Bella, R. (2020). Analisis Psikologi Perkembangan Sosial Emosional Anak Usia dini. Bunayya: Jurnal Pendidikan Anak, 6(2), 156-171.

[10] Shalehah, A., Hidayatullah, M. S., \& Rachmah, D. N. (2020). PENERAPAN COOPERATIVE PLAY DALAM BENTUK PERMAINAN KONSTRUKTIF UNTUK MENINGKATKAN KETERAMPILAN SOSIAL PADA ANAK USIA DINI. Kognisia prodi Psikologi FK ULM, 1(2), 83-94.

[11] Tabi'in, A. (2017). Menumbuhkan sikap peduli pada anak melalui interaksi kegiatan sosial. IJTIMAIYA: Journal of Social Science Teaching, 1(1).

[12] Mayar, F. (2013). Perkembangan sosial anak usia dini sebagai bibit untuk masa depan bangsa. Al-Ta lim Journal, 20(3), 459-464. 